\title{
The Method of Comprehensive Development Assessment based on Multy-Component Analysis
}

\author{
Submitted 23/08/19, 1st revision 12/09/19, 2nd revision 17/10/19, accepted 23/11/19
}

Anna Pereverzieva ${ }^{1}$, Volodymyr Volkov ${ }^{2}$

\begin{abstract}
:
Purpose: Sustainable, inclusive progress, accompanied by income growth along with higher opportunities, quality of life, and environmental security, should be recognized as the key goal of any society. Moreover, development must necessarily include quality indicators, which reflect the compliance of the created economic environment with people's expectations. Therefore the aim of this research is to create a comprehensive index that combines quantitative and qualitative development indicators and identifies areas that need further attention and research.

Design/Methodology/Approach: Unlike commonly accepted method of element by element development assessment, the method for calculating integrated development index for the EU member-states during 2016-2017s has been proposed in the article as well as the scenario forecasting up to 2020. The study is aimed at a hypothesis testing as: despite high income level, the country may experience low life satisfaction.

Findings: Based on the analysis, it has been determined that countries with highest rates of human development occupy lower ranks according to the satisfaction with life index. Our comprehensive development index, which integrates human development index, the satisfaction with life and environmental performance index, has allowed us to identify countries that have balanced development of their economic-human-ecological systems.

Practical Implications: Trend of decreasing value of the comprehensive development index of almost all EU member countries due to the reduction of their integrate indicators raise doubts. This may mean that EU member states' development will have slower, and subsequently negative dynamics. The results of scenario forecasting have confirmed it, without changing the priority from quantitative indicators to qualitative ones.

Originality/Value: The study proves the need to take into account both objective and subjective development indicators in order to improve them and reach the overall goals of the EU. This will strengthen EU's international status.
\end{abstract}

Keywords: Comprehensive development, life index, EU member states.

JEL codes: 011,015

Paper type : Research article.

\footnotetext{
${ }^{1}$ Corresponding author, Zaporizhzhya national university, International Economy, Natural

Resources and Economics International Tourism, pereverzeva@ukr.net

${ }^{2}$ Zaporizhzhya national university, Department of Entrepreneurship, Management of

Organizations and Logistics, volkovp49@gmail.com
} 


\section{Introduction}

In the context of reform processes' intensification, there is a need to formulate a new philosophy of integration development in general and of individual countries in particular, which should be based on the principles of balanced development. Balanced development is a topical issue for all EU member-states. The mismatch between economic development rates and environmental standards, the dominance of industries with high share of resource- and energy-intensive technologies, resource-biased exports, low labour culture and consumption caused crisis of ecosystems that adversely affect human and social life.

Now income and wealth inequality is one of the urgent problems, but financial reward is only one of the elements that ensures well-being. Education, life expectancy and employment are equally important. That is, the limits of this approach are quite clear, as it determines growth only through financial reward. It should be noted that one could have high economic growth rates and considerable inequality in distribution of goods between market players. Therefore, there is a need to ensure development that creates equal opportunities for all social groups as well as "dividends" distribution both in tangible and intangible form based on rationality and fairness principles.

Comprehensive development, accompanied by rising incomes, along with better economic opportunities, life satisfaction, protection and quality of life, should be recognized as the overriding goal of any government. Besides, comprehensive development implies living standard boost and compliance of living conditions with personal expectations, not just the rise of production of goods and services. Low life satisfaction and high rate of human development show disproportionality and require internal policy improvement refocused on favorable living environment.

Hence, it should be noted that the index of comprehensive development can be a simultaneous combination of the current state and prospects evidenced by the elements in its structure, which, on the one hand, determine the achieved result, and on the other, form the directions that require support to ensure balance and compliance of the economic environment with people's expectations. Statistical diagnostics of the EU member-states development confirms the need to achieve a high level of comprehensive development not only by boosting quantitative indicators, but also by qualitative indicators' improvement. This requires, on the one hand, creating living environment and participating in the process of economic environment modelling, and on the other, assessment and control of life satisfaction. Therefore we propose the following hypotheses for testing:

H1: Countries scoring higher human development index do not have to be topranked country for the life satisfaction index;

H2: The comprehensive development index includes many-component of country's development; 
H3: The development of a member-state of any association affects its internal and external relations' strength as well as its sustainability.

\section{Materials and Methods}

The comprehensive development index for the EU, which includes three dimensions, has been calculated in this article as: (1) the human development index, (2) the satisfaction with life index ("happiness"), (3) the environmental performance index. Two models are applied for calculations; the first is additive, which assumes that low values of one indicator are offset by higher values of other indicators. The second is multiplicative, which includes all the indicators, that is, determines comprehensive development. The second model allows to test hypothesis about possibility for balanced development amid high objective and subjective indices. In addition, the forecasting of the EU member-states comprehensive development by 2020 has been provided. The methods of descriptive, statistical and comparative analysis, economic and mathematical modeling, scenario forecasting have been applied in the study.

\section{Results}

It is a common international practice to rank countries according to certain criteria like human development, life satisfaction ("happiness"), environmental performance, etc. The human development combines three dimensions: GDP per capita, education index, life expectancy index. Statistical data for the human development index of the EU member-states (HDI) are presented in Table 1.

Table 1. The human development index of the EU member states

\begin{tabular}{|l|l|l|l|}
\hline \multirow{2}{*}{ № } & Countries & \multicolumn{2}{l|}{$\begin{array}{l}\text { The human development index } \\
\text { (HDI) }\end{array}$} \\
\cline { 3 - 4 } & & $2016 \mathrm{p}$. & $2017 \mathrm{p}$. \\
\hline 1 & Austria & 0,938 & 0,939 \\
\hline 2 & Belgium & 0,915 & 0,916 \\
\hline 3 & Bulgaria & 0,810 & 0,813 \\
\hline 4 & Great Britain & 0,920 & 0,922 \\
\hline 5 & Hungary & 0,835 & 0,838 \\
\hline 6 & Germany & 0,934 & 0,936 \\
\hline 7 & Greece & 0,868 & 0,870 \\
\hline 8 & Denmark & 0,928 & 0,929 \\
\hline 9 & Ireland & 0,934 & 0,938 \\
\hline
\end{tabular}

\begin{tabular}{|l|l|l|l|}
\hline 10 & Spain & 0,889 & 0,891 \\
\hline 11 & Italy & 0,878 & 0,880 \\
\hline 12 & Latvia & 0,844 & 0,847 \\
\hline 13 & Lithuania & 0,855 & 0,858 \\
\hline 14 & Luxemburg & 0,904 & 0,904 \\
\hline 15 & Netherland & 0,928 & 0,931 \\
\hline
\end{tabular}


The Method of Comprehensive Development Assessment based on Multy-Component Analysis

\begin{tabular}{|l|l|l|l|}
\hline 16 & Poland & 0,860 & 0,865 \\
\hline 17 & Portugal & 0,845 & 0,847 \\
\hline 18 & Romania & 0,807 & 0,811 \\
\hline 19 & Slovenia & 0,894 & 0,896 \\
\hline 20 & Finland & 0,918 & 0,920 \\
\hline 21 & France & 0,899 & 0,901 \\
\hline 22 & Croatia & 0,828 & 0,831 \\
\hline 23 & the Czech Republic & 0,885 & 0,888 \\
\hline 24 & Sweden & 0,932 & 0,933 \\
\hline 25 & Estonia & 0,868 & 0,871 \\
\hline \multicolumn{2}{|l|}{ Mean for the EU member states } & 0,847 & 0,849 \\
\hline
\end{tabular}

Source: Human Development Data (1990-2017) / UNITED NATIONS DEVELOPMENT

PROGRAMME Human Development Reports. http://hdr.undp.org/en/data.

The satisfaction with life index ("the happiness index") determines whether living standards and environment fit life expectations. This indicator's values for the EU member-states are presented in Table 2.

Table 2. The happiness index of the EU member states

\begin{tabular}{|c|c|c|c|}
\hline \multirow{2}{*}{ № } & \multirow{2}{*}{ Country } & \multicolumn{2}{|c|}{ The happiness index (HAP) } \\
\hline & & 2016 & 2017 \\
\hline 1 & Austria & 7,01 & 7,14 \\
\hline 2 & Belgium & 6,89 & 6,93 \\
\hline 3 & Bulgaria & 4,71 & 4,93 \\
\hline 4 & Great Britain & 6,71 & 6,81 \\
\hline 5 & Hungary & 5,32 & 5,62 \\
\hline 6 & Germany & 6,95 & 6,97 \\
\hline 7 & Greece & 5,23 & 5,36 \\
\hline 8 & Denmark & 7,52 & 7,56 \\
\hline 9 & Ireland & 6,98 & 6,98 \\
\hline 10 & Spain & 6,40 & 6,31 \\
\hline 11 & Italy & 5,96 & 6,00 \\
\hline 12 & Latvia & 5,85 & 5,93 \\
\hline 13 & Lithuania & 5,90 & 5,95 \\
\hline 14 & Luxemburg & 6,86 & 6,91 \\
\hline 15 & Netherland & 7,38 & 7,44 \\
\hline 16 & Poland & 5,97 & 6,12 \\
\hline 17 & \begin{tabular}{|l|} 
Portugal \\
\end{tabular} & 5,20 & 5,41 \\
\hline 18 & Romania & 5,83 & 5,95 \\
\hline 19 & Slovenia & 5,76 & 5,95 \\
\hline 20 & \begin{tabular}{|l|} 
Finland \\
\end{tabular} & 7,47 & 7,63 \\
\hline 21 & France & 6,44 & 6,49 \\
\hline 22 & Croatia & 5,29 & 5,32 \\
\hline 23 & the Czech Republic & 6,61 & 6,71 \\
\hline 24 & Sweden & 7,28 & 7,31 \\
\hline
\end{tabular}




\begin{tabular}{|l|l|l|l|}
\hline 25 & Estonia & 5,61 & 5,74 \\
\hline \multicolumn{2}{|l|}{ Mean for the EU member states } & 6,00 & 6,09 \\
\hline
\end{tabular}

Source: World Happiness Report 2017. URL: https://s3.amazonaws.com/happinessreport/2017/HR17.pdf.

World Happiness Report 2018 URL: https://s3.amazonaws.com/happinessreport/2018/HR18.pdf.

The indicator which identifies the level of environmental performance has been also used in the article as in Table 3.

Table 3. The environmental performance index of the EU member states

\begin{tabular}{|c|c|c|c|}
\hline \multirow[t]{2}{*}{ № } & \multirow[t]{2}{*}{ Country } & \multicolumn{2}{|c|}{$\begin{array}{l}\text { The environmental performance } \\
\text { index } \\
\text { (EPI) }\end{array}$} \\
\hline & & 2016 & 2017 \\
\hline 1 & Austria & 88,84 & 78,97 \\
\hline 2 & Belgium & 80,15 & 77,38 \\
\hline 3 & Bulgaria & 83,40 & 67,85 \\
\hline 4 & Great Britain & 87,38 & 79,89 \\
\hline 5 & Hungary & 84,80 & 65,01 \\
\hline 6 & Germany & 84,26 & 78,37 \\
\hline 7 & Greece & 85,81 & 73,6 \\
\hline 8 & Denmark & 80,21 & 81,60 \\
\hline 9 & Ireland & 86,80 & 78,77 \\
\hline 10 & Spain & 88,91 & 78,39 \\
\hline 11 & Italy & 84,48 & 76,96 \\
\hline 12 & Latvia & 85,71 & 66,12 \\
\hline 13 & Lithuania & 85,40 & 69,33 \\
\hline 14 & Luxemburg & 88,58 & 79,12 \\
\hline 15 & Netherland & 82,03 & 75,46 \\
\hline 16 & Poland & 81,26 & 64,11 \\
\hline 17 & Portugal & 88,63 & 71,91 \\
\hline 18 & Romania & 83,24 & 64,78 \\
\hline 19 & Slovenia & 88,98 & 67,57 \\
\hline 20 & Finland & 90,68 & 78,64 \\
\hline 21 & France & 88,20 & 83,95 \\
\hline 22 & Croatia & 86,98 & 65,45 \\
\hline 23 & the Czech Republic & 84,87 & 67,68 \\
\hline 24 & Sweden & 90,43 & 80,51 \\
\hline 25 & Estonia & 88,50 & 64,31 \\
\hline \multicolumn{2}{|c|}{ Mean for the EU member states } & 82,39 & 70,27 \\
\hline
\end{tabular}

Source: Environmental Performance Index 2016. New Haven, CT: Yale University. URL: www.epi.yale.edu. 
Wendling, Z.A., Emerson, J.W., Esty, D.C. and Levy, M.A. et al. 2018. Environmental

Performance Index. New Haven, CT: Yale Center for Environmental Law \& Policy.

URL:https:/lepi.yale.edu/

In our opinion, each indicator's separate analysis represents only national progress' aspect. This limits its future development. Therefore, it is important to consider all dimensions at the same time, which testifies comprehensive and multidimensional development. We propose to define the overall index as a set of three indicators: the human development index, the satisfaction with life index ("happiness") and the environmental performance index.

To calculate the overall index, you need to bring indices into correspondence with each other by normalization. The process of indices calculation applies normalization of statistical indicators. We will do it by the formula:

$I_{z}=\frac{Z_{f a c t}}{Z_{\max }}$,

where $I_{z}$ - normalized index;

$Z_{\text {fact }}$ - factual index value;

$Z_{\max }-$ maximum index value (for the inclusive development index - 10; for the happiness index - 10; for the environmental sustainability - 100);

The human development index is a normalized one. The results of the life satisfaction index and the environmental performance index normalization are presented in Tables 4-5.

Table 4. Normalization of the happiness index for the EU countries

\begin{tabular}{|l|l|l|l|}
\hline \multirow{2}{*}{ № } & \multirow{2}{*}{ Country } & $\begin{array}{l}\text { The happiness index } \\
\left(\boldsymbol{I}_{\text {HAP }}\right)\end{array}$ \\
\cline { 3 - 4 } & & $2016 \mathrm{p}$. & $2017 \mathrm{p}$. \\
\hline 1 & Austria & 0,701 & 0,714 \\
\hline 2 & Belgium & 0,689 & 0,693 \\
\hline 3 & Bulgaria & 0,471 & 0,493 \\
\hline
\end{tabular}

\begin{tabular}{|l|l|l|l|}
\hline & & & \\
\hline 4 & Great Britain & 0,671 & 0,681 \\
\hline 5 & Hungary & 0,532 & 0,562 \\
\hline 6 & Germany & 0,695 & 0,697 \\
\hline 7 & Greece & 0,523 & 0,536 \\
\hline 8 & Denmark & 0,752 & 0,756 \\
\hline 9 & Ireland & 0,698 & 0,698 \\
\hline 10 & Spain & 0,64 & 0,631 \\
\hline 11 & Italy & 0,596 & 0,6 \\
\hline
\end{tabular}




\begin{tabular}{|l|l|l|l|}
\hline 12 & Latvia & 0,585 & 0,593 \\
\hline 13 & Lithuania & 0,59 & 0,595 \\
\hline 14 & Luxemburg & 0,686 & 0,691 \\
\hline 15 & Netherland & 0,738 & 0,744 \\
\hline 16 & Poland & 0,597 & 0,612 \\
\hline 17 & Portugal & 0,52 & 0,541 \\
\hline 18 & Romania & 0,583 & 0,595 \\
\hline 19 & Slovenia & 0,576 & 0,595 \\
\hline 20 & Finland & 0,747 & 0,763 \\
\hline 21 & France & 0,644 & 0,649 \\
\hline 22 & Croatia & 0,529 & 0,532 \\
\hline 23 & the Czech Republic & 0,661 & 0,671 \\
\hline 24 & Sweden & 0,728 & 0,731 \\
\hline 25 & Estonia & 0,561 & 0,574 \\
\hline Mean for the EU member states & 0,600 & 0,609 \\
\hline
\end{tabular}

Source: Own calculations.

Table 5. Normalization of the environmental performance index for the EU countries

\begin{tabular}{|l|l|l|l|}
\hline \multirow{2}{*}{ № } & Country & \multicolumn{2}{l|}{$\begin{array}{l}\text { The environmental performance } \\
\text { index } \\
\text { (EPI) }\end{array}$} \\
\cline { 3 - 4 } & & $2016 \mathrm{p}$. & $2017 \mathrm{p}$. \\
\hline 1 & & 0,888 & 0,790 \\
\hline 2 & Austria & 0,802 & 0,774 \\
\hline 3 & Belgium & 0,834 & 0,679 \\
\hline 4 & Bulgaria & 0,874 & 0,799 \\
\hline 5 & Great Britain & 0,848 & 0,650 \\
\hline 6 & Hungary & 0,843 & 0,784 \\
\hline 7 & Germany & 0,858 & 0,736 \\
\hline 8 & Greece & 0,802 & 0,816 \\
\hline 9 & Denmark & 0,868 & 0,788 \\
\hline 10 & Ireland & 0,889 & 0,784 \\
\hline 11 & Spain & 0,845 & 0,770 \\
\hline 12 & Italy & 0,857 & 0,661 \\
\hline 13 & Latvia & 0,854 & 0,693 \\
\hline 14 & Lithuania & 0,886 & 0,791 \\
\hline
\end{tabular}

\begin{tabular}{|l|l|l|l|}
\hline 15 & Netherland & 0,820 & 0,755 \\
\hline 16 & Poland & 0,813 & 0,641 \\
\hline 17 & Portugal & 0,886 & 0,719 \\
\hline 18 & Romania & 0,832 & 0,648 \\
\hline 19 & Slovenia & 0,890 & 0,676 \\
\hline 20 & Finland & 0,907 & 0,786 \\
\hline 21 & France & 0,882 & 0,840 \\
\hline 22 & Croatia & 0,870 & 0,655 \\
\hline 23 & the Czech Republic & 0,849 & 0,677 \\
\hline
\end{tabular}




\begin{tabular}{|l|l|l|l|}
\hline 24 & Sweden & 0,904 & 0,805 \\
\hline 25 & Estonia & 0,885 & 0,643 \\
\hline \multicolumn{2}{|l|}{ Mean for the EU member states } & 0,824 & 0,703 \\
\hline
\end{tabular}

Source: Own calculations.

For the profound analysis of the country's comprehensive development index calculation we propose two models: additive and multiplicative. Applying the alternative models to calculate the comprehensive development index considerably widens study's opportunities according to its strategic priorities. The additive model is the first model in which indices are balanced when higher values of some indicators offset the low values of other. The model gives the highest result but does not provide possibility to determine each element's contribution to the overall development. Thus the country`s comprehensive development index according to the additive model is presented as:

$$
I_{\text {total }}=\frac{I_{H D}+I_{H A P}+I_{E P I}}{3}
$$

where $I_{\text {total }}$ - the country`s comprehensive development index;

$I_{H D}$ - the human development index;

$I_{H A P}$ - the satisfaction with life index ("the happiness index");

$I_{E P I}$ - the environmental performance index.

The multiplicative model provides the opportunity to consider all indicators together. The model is more "strict", as it does not allow to offset low indices' values by those with high rates. In our consideration, it is efficient to apply it when there is the need to take into account all integral parts, which determine quantitative and qualitative development of a country.

Thus, country's comprehensive development index in accordance with the multiplicative model is calculated by the formula:

$$
I_{\text {total }}=\sqrt[3]{I_{H D} \cdot I_{H A P} \cdot I_{E P I}}
$$

where $I_{\text {total }}$ - the country`s comprehensive development index ;

$I_{H D}$ - the human development index;

$I_{H A P}$ - the satisfaction with life index ("the happiness index");

$I_{E P I}$ - the environmental performance index.

The multiplicative model's advantage is possibility to take into account and harmonize low and high indicators' values. It also reflects correspondence of the 
calculated comprehensive development index to actual conditions. Additive model, in turn, is applied with the result that low indicators' values offset high values of others, which leads to the inflated value of the country's comprehensive development index. Let us calculate the comprehensive development index by the additive and multiplicative models for the EU member-states (Table 6).

Table 6. The comprehensive development index for the EU countries

\begin{tabular}{|l|l|l|l|l|l|}
\hline \multirow{2}{*}{$№$} & \multirow{3}{*}{ Country } & \multicolumn{4}{l|}{ The comprehensive development index $\left(I_{\text {total }}\right)$} \\
\cline { 3 - 6 } & & \multicolumn{3}{|l|}{ Additive model } & \multicolumn{2}{l|}{ Multiplicative model } \\
\cline { 3 - 6 } & & 2016 & 2017 & 2016 & 2017 \\
\hline 1 & Austria & 0,842 & 0,814 & 0,836 & 0,809 \\
\hline 2 & Belgium & 0,802 & 0,794 & 0,797 & 0,789 \\
\hline 3 & Bulgaria & 0,705 & 0,662 & 0,683 & 0,648 \\
\hline 4 & Great Britain & 0,822 & 0,801 & 0,814 & 0,795 \\
\hline 5 & Hungary & 0,738 & 0,683 & 0,722 & 0,674 \\
\hline 6 & Germany & 0,824 & 0,806 & 0,818 & 0,800 \\
\hline 7 & Greece & 0,750 & 0,714 & 0,730 & 0,700 \\
\hline 8 & Denmark & 0,827 & 0,834 & 0,824 & 0,831 \\
\hline 9 & Ireland & 0,833 & 0,808 & 0,827 & 0,802 \\
\hline 10 & Spain & 0,806 & 0,769 & 0,797 & 0,761 \\
\hline 11 & Italy & 0,773 & 0,750 & 0,762 & 0,741 \\
\hline 12 & Latvia & 0,762 & 0,700 & 0,751 & 0,692 \\
\hline 13 & Lithuania & 0,766 & 0,715 & 0,755 & 0,707 \\
\hline 14 & Luxemburg & 0,825 & 0,795 & 0,819 & 0,791 \\
\hline 15 & Netherland & 0,829 & 0,810 & 0,825 & 0,806 \\
\hline 16 & Poland & 0,757 & 0,706 & 0,747 & 0,697 \\
\hline 17 & Portugal & 0,750 & 0,702 & 0,730 & 0,691 \\
\hline 18 & Romania & 0,741 & 0,685 & 0,732 & 0,679 \\
\hline 19 & Slovenia & 0,787 & 0,722 & 0,771 & 0,712 \\
\hline 20 & Finland & 0,857 & 0,823 & 0,854 & 0,820 \\
\hline 21 & France & 0,808 & 0,797 & 0,799 & 0,789 \\
\hline 22 & Croatia & 0,742 & 0,673 & 0,725 & 0,662 \\
\hline 23 & the Czech Republic & 0,798 & 0,745 & 0,792 & 0,739 \\
\hline 24 & Sweden & 0,855 & 0,823 & 0,850 & 0,819 \\
\hline 25 & Estonia & 0,771 & 0,696 & 0,755 & 0,685 \\
\hline Mean for the EU member states & 0,757 & 0,720 & 0,748 & 0,714 \\
\hline
\end{tabular}

Source: Own calculations.

Analysis of the calculated comprehensive development index (Table 6) demonstrates that only Denmark from 25 EU member-states has positive trend, that is the index grows from 0,827 in 2016 to 0,834 in 2017 according to the additive model and from 0,824 in 2016 to 0,831 in 2017 by the multiplicative model. Hungary, Latvia, Lithuania, Poland, Portugal, Romania, Slovenia, Croatia and Estonia had low than average comprehensive development index for the EU member-states in 2017. That is $40 \%$ of the EU member-states need to improve their internal development policy 
based on financial resource distribution and elimination of the bottlenecks. This will allow not only increasing national development level but also tightening the EU integrity and guaranteeing sustainability to external threats.

We think that to force the efficiency of managerial decision-making, it is important to determine each integral part's contribution to the overall development value. Calculation of each development integral part's contribution allows to manage them using monetary and non-monetary tools. Contribution of the human development, satisfaction with life and environmental performance indices is determined based on the theory of indices, i.e. approach to the gross growth of final criteria (the comprehensive development index) by determinants (integral parts of comprehensive development). There are two main trends among them. They include a few modifications: method of chain substitutions (or the method of interrelated determinants impact) and method of isolated impact [1-3].

We should emphasize that method of chain substitutions implies determinants adjustment in a certain sequence: development $\rightarrow$ satisfaction with life $\rightarrow$ environmental efficiency. It is advisable to apply the method of isolated impact, which includes consecutive change of determinants when fixing other at the basic level. Thus share of each determinant in index`s growth does not depend on the sequence of other determinants`impact revealing on it and the result.

The contribution of each integral part into the common level of the comprehensive development based on the method of isolated impact is calculated based on the absolute partial increment of final criteria - the comprehensive development index. Theoretical background of the method and its practical implementation according to the EU statistics allow to form the next analytical dependencies:

$$
\begin{aligned}
& \Delta I_{\text {total }}{ }^{H D}=\sqrt[3]{I_{H D}{ }^{1} I_{H A P}{ }^{0} I_{E P I}{ }^{0}-I_{H D}{ }^{0} I_{H A P}{ }^{0} I_{E P I}{ }^{0}} \\
& \Delta I_{\text {total }}{ }^{H A P}=\sqrt[3]{I_{H D}{ }^{0} I_{H A P}{ }^{1} I_{E P I}{ }^{0}-I_{H D}{ }^{0} I_{H A P}{ }^{0} I_{E P I}{ }^{0}} \\
& \Delta I_{\text {total }}{ }^{E P I}=\sqrt[3]{I_{H D}{ }^{0} I_{H A P}{ }^{0} I_{E P I}{ }^{1}-I_{H D}{ }^{0} I_{H A P}{ }^{0} I_{E P I}{ }^{0}}
\end{aligned}
$$

where $\Delta I_{\text {total }}{ }^{H D}$ - increment of the comprehensive development index on account of human development level's change; $\Delta I_{\text {total }}{ }^{\text {HAP }}$ - increment of the comprehensive development index on account of satisfaction with life level change;

$\Delta I_{\text {total }}{ }^{E P I}$ - increment of the comprehensive development index on account of environmental performance change.

0 and 1- indicate base (2016) and current periods (2017). 
The advantage of the method of isolated impact is the possibility to calculate contribution into the common development level of each component's interactions. To do this we apply the next formula:

$\Delta I_{\text {total }}^{\text {int eraction }}=\Delta I_{\text {total }}-\left(\Delta I_{\text {total }}^{H D}+I_{\text {total }}^{H A P}+\Delta I_{\text {total }}{ }^{E P I}\right)$

where $\Delta I_{\text {total }}^{\text {int eraction }}$ - increment of the comprehensive development index on account of its components interactions.

Practical implementation of the method of isolated impact is presented by the example of the EU countries. Multiplicative model is used considering 2016 as a base period and 2017 as a current period (Table 7).

Table 7. Assessment of the elements input to the overall development of the EU member states based on the method of isolated impact

\begin{tabular}{|l|l|l|l|l|l|l|}
\hline \multirow{2}{*}{$№$} & Country & $\Delta I_{\text {total }}^{H D}$ & $\Delta I_{\text {total }}^{H 4}$ & $\Delta I_{\text {total }}^{E P I}$ & $\Delta I_{\text {total }}$ & $\Delta I_{\text {total }}^{\text {int eraction }}$ \\
\cline { 3 - 7 } & & & & & & \\
\hline 1 & Austria & Austria & 0,221 & $-0,401$ & $-0,054$ & 0,040 \\
\hline 2 & Belgium & Belgium & 0,143 & $-0,260$ & $-0,014$ & 0,021 \\
\hline 3 & Bulgaria & Bulgaria & 0,246 & $-0,390$ & $-0,046$ & $-0,008$ \\
\hline 4 & Great Britain & Great & & & & \\
& & Britain & 0,200 & $-0,359$ & $-0,038$ & 0,015 \\
\hline 5 & Hungary & Hungary & 0,277 & $-0,445$ & $-0,071$ & $-0,013$ \\
\hline 6 & Germany & Germany & 0,116 & $-0,337$ & $-0,036$ & 0,080 \\
\hline 7 & Greece & Greece & 0,213 & $-0,381$ & $-0,046$ & 0,025 \\
\hline 8 & Denmark & Denmark & 0,144 & 0,214 & 0,013 & $-0,429$ \\
\hline 9 & Ireland & Ireland & 0,000 & $-0,374$ & $-0,050$ & 0,189 \\
\hline 10 & Spain & Spain & $-0,192$ & $-0,391$ & $-0,065$ & 0,414 \\
\hline 11 & Italy & Italy & 0,144 & $-0,340$ & $-0,036$ & 0,060 \\
\hline 12 & Latvia & Latvia & 0,180 & $-0,459$ & $-0,091$ & 0,074 \\
\hline 13 & Lithuania & Lithuania & 0,154 & $-0,433$ & $-0,077$ & 0,087 \\
\hline 14 & Luxemburg & Luxemburg & 0,159 & $-0,389$ & $-0,055$ & 0,175 \\
\hline 15 & Netherland & Netherland & 0,166 & $-0,354$ & $-0,039$ & 0,028 \\
\hline 16 & Poland & Poland & 0,219 & $-0,445$ & $-0,078$ & 0,014 \\
\hline 17 & Portugal & Portugal & 0,251 & $-0,419$ & $-0,060$ & 0,011 \\
\hline 18 & Romania & Romania & 0,200 & $-0,442$ & $-0,079$ & 0,038 \\
\hline 19 & Slovenia & Slovenia & 0,247 & $-0,479$ & $-0,098$ & 0,033 \\
\hline 20 & Finland & Finland & 0,237 & $-0,436$ & $-0,070$ & 0,018 \\
\hline 21 & France & France & 0,158 & $-0,290$ & $-0,019$ & 0,008 \\
\hline 22 & Croatia & Croatia & 0,129 & $-0,455$ & $-0,092$ & 0,123 \\
\hline 23 & Czech Republic & $\begin{array}{l}\text { Czech } \\
\text { Republic }\end{array}$ & 0,196 & $-0,465$ & $-0,093$ & 0,057 \\
\hline & & & & & & \\
\hline
\end{tabular}




\begin{tabular}{|l|l|l|l|l|l|l|}
\hline 24 & Sweden & Sweden & 0,136 & $-0,407$ & $-0,064$ & 0,119 \\
\hline 25 & Estonia & Estonia & 0,215 & $-0,490$ & $-0,109$ & 0,051 \\
\hline $\begin{array}{l}\text { Mean for the EU } \\
\text { member states }\end{array}$ & 0,100 & 0,185 & $-0,395$ & $-0,055$ & 0,055 \\
\hline
\end{tabular}

Source: Own calculations.

Mean value of components increment by the EU member-states is presented in Table 8.

Table 8. Mean of the comprehensive development components increment by the method of isolated impact

\begin{tabular}{|l|l|l|}
\hline Indices & Absolute value & percent, \% \\
\hline$\Delta I_{\text {total }}^{H D}$ & 0,100 & 10 \\
\hline$\Delta I_{\text {total }}^{H A P}$ & 0,185 & 18,5 \\
\hline$\Delta I_{\text {total }}^{E P I}$ & $-0,395$ & $-39,5$ \\
\hline$\Delta I_{\text {total }}^{\text {int eraction }}$ & 0,055 & 5,5 \\
\hline
\end{tabular}

Source: Own calculations.

Table 8 data analysis proves that the average level of comprehensive development for the EU member-states is determined by the satisfaction with life for 18,5\%, human development for $10,0 \%$ and environmental performance for $39,5 \%$. It should be noted that the human development index and the satisfaction with life index indicate direct impact, whilst the environmental performance index shows the adverse effect and decreases comprehensive development level.

The method of chain substitutions is the alternative for determinants contribution identification by the method of isolated factors. Based on the obtained results we consider the next sequence of the integral parts' impact: human development $\rightarrow$ satisfaction with life $\rightarrow$ environmental performance (the sequence corresponds to their values). The method of chain substitutions specifies formulas application:

$$
\begin{aligned}
& \Delta I_{\text {total }}{ }^{H D}=\sqrt[3]{I_{H D}{ }^{1} I_{H A P}{ }^{0} I_{E P I}{ }^{0}-I_{H D}{ }^{0} I_{H A P}{ }^{0} I_{E P I}{ }^{0}} \\
& \Delta I_{\text {total }}{ }^{H A P}=\sqrt[3]{I_{H D}{ }^{1} I_{H A P}{ }^{1} I_{E P I}{ }^{0}-I_{H D}{ }^{1} I_{H A P}{ }^{0} I_{E P I}{ }^{0}} \\
& \Delta I_{\text {total }}{ }^{E P I}=\sqrt[3]{I_{H D}{ }^{1} I_{H A P}{ }^{1} I_{E P I}{ }^{1}-I_{H D}{ }^{1} I_{H A P}{ }^{1} I_{E P I}{ }^{0}} \\
& \Delta I_{\text {total }}=\Delta I_{\text {total }}{ }^{H D}+I_{\text {total }}{ }^{H A P}+\Delta I_{\text {total }}{ }^{E P I}
\end{aligned}
$$


where $\Delta I_{\text {total }}{ }^{H D}$ - increment of the comprehensive development index on account of human development level change;

$\Delta I_{\text {total }}^{\text {HAP }}$ - increment of the comprehensive development index on account of satisfaction with life level change;

$\Delta I_{\text {total }}{ }^{E P I}$ - increment of the comprehensive development index on account of environmental performance change;

$\Delta I_{\text {total }}$ - total increment of the comprehensive development index.

0 and $1-$ indicate base and current periods.

The calculation results for the components' contribution into the comprehensive development are presented in Table 9.

Table 9. Assessment of components contribution into the overall development level of the EU member-states based on the method of chain substitutions

\begin{tabular}{|c|c|c|c|c|c|}
\hline \multirow[t]{2}{*}{ № } & \multirow[t]{2}{*}{ Countries } & \multicolumn{4}{|c|}{ Components of the comprehensive development } \\
\hline & & $\Delta I_{\text {total }}{ }^{H D}$ & $\Delta I_{\text {total }}{ }^{H A P}$ & $\Delta I_{\text {total }} E P I$ & $\Delta I_{\text {total }}$ \\
\hline 1 & Austria & 0,085 & 0,221 & $-0,404$ & $-0,097$ \\
\hline 2 & Belgium & 0,082 & 0,143 & $-0,261$ & $-0,036$ \\
\hline 3 & Bulgaria & 0,106 & 0,246 & $-0,396$ & $-0,044$ \\
\hline 4 & Great Britain & 0,105 & 0,200 & $-0,361$ & $-0,055$ \\
\hline 5 & Hungary & 0,111 & 0,277 & $-0,453$ & $-0,066$ \\
\hline 6 & Germany & 0,105 & 0,116 & $-0,338$ & $-0,116$ \\
\hline 7 & Greece & 0,096 & 0,213 & $-0,385$ & $-0,075$ \\
\hline 8 & Denmark & 0,084 & 0,144 & 0,214 & 0,443 \\
\hline 9 & Ireland & 0,134 & 0,000 & $-0,374$ & $-0,240$ \\
\hline 10 & Spain & 0,104 & $-0,192$ & $-0,389$ & $-0,477$ \\
\hline 11 & Italy & 0,100 & 0,144 & $-0,341$ & $-0,097$ \\
\hline 12 & Latvia & 0,115 & 0,180 & $-0,462$ & $-0,167$ \\
\hline 13 & Lithuania & 0,115 & 0,154 & $-0,435$ & $-0,166$ \\
\hline 14 & Luxemburg & 0,000 & 0,159 & $-0,390$ & $-0,231$ \\
\hline 15 & Netherland & 0,122 & 0,166 & $-0,356$ & $-0,068$ \\
\hline 16 & Poland & 0,134 & 0,219 & $-0,450$ & $-0,096$ \\
\hline 17 & Portugal & 0,097 & 0,251 & $-0,425$ & $-0,077$ \\
\hline 18 & Romania & 0,125 & 0,201 & $-0,446$ & $-0,121$ \\
\hline 19 & Slovenia & 0,101 & 0,247 & $-0,485$ & $-0,137$ \\
\hline 20 & Finland & 0,111 & 0,237 & $-0,440$ & $-0,092$ \\
\hline 21 & France & 0,104 & 0,158 & $-0,291$ & $-0,028$ \\
\hline 22 & Croatia & 0,111 & 0,129 & $-0,456$ & $-0,216$ \\
\hline 23 & the Czech Republic & 0,119 & 0,196 & $-0,468$ & $-0,153$ \\
\hline 24 & Sweden & 0,087 & 0,136 & $-0,407$ & $-0,184$ \\
\hline
\end{tabular}




\begin{tabular}{|l|l|l|l|l|l|}
\hline 25 & Estonia & 0,114 & 0,216 & $-0,495$ & $-0,165$ \\
\hline \multicolumn{2}{|l}{ Mean for the EU member-states } & 0,100 & 0,185 & $-0,397$ & $-0,113$ \\
\hline
\end{tabular}

Source: Own calculations.

Mean value of components' increments by the EU member-states is presented in Table 10 .

Based on Table 10 data analysis it should be stressed that the human development index contribution into the total level of the EU member-states' comprehensive development is $11 \%$, the satisfaction with life index is $18,5 \%$ environmental performance`s is (-)39,7\% taking into account certain components` sequence on accordance with properly applied method of chain substitutions. Total components contribution into the comprehensive development is (-) $11,3 \%$, which testifies the need to choose another components sequence.

Table 10. Mean value of increments of the comprehensive development components by the method of chain substitutions

\begin{tabular}{|l|l|l|}
\hline Indices & Absolute value & percent, $\%$ \\
\hline$\Delta I_{\text {total }}^{H D}$ & 0,110 & 11 \\
\hline$\Delta I_{\text {total }}^{H A P}$ & 0,185 & 18,5 \\
\hline$\Delta I_{\text {totsl }}^{E P I}$ & $-0,397$ & $-39,7$ \\
\hline$\Delta I_{\text {total }}^{\text {int } \text { eraction }}$ & $-0,113$ & 11,3 \\
\hline
\end{tabular}

Source: Own calculations.

We consider, that forecasting of the EU member-states` development prospects according to the selected indices has to be done based on the comprehensive development index taking into account its compound structure.

We apply the next formula for the scenario forecasting of the comprehensive development:

$$
I_{\text {total }}=\sqrt[3]{I_{H D} \cdot I_{H A P} \cdot I_{E P I}}
$$

where $I_{\text {total }}$ - state comprehensive development index;

$I_{H D}$ - the human development index;

$I_{H A P}$ - the satisfaction with life index («happiness»);

$I_{E P I}$ - the environmental performance index.

Forecasting of the possible changes in the comprehensive development index affected by the dynamic modifications will be done applying two model: additive and multiplicative (Table 11). 
Table 11. Change in the comprehensive development index of the EU member-states during 2016-2017

\begin{tabular}{|c|c|c|c|c|c|c|c|}
\hline \multirow[t]{3}{*}{ № } & \multirow[t]{3}{*}{ Country } & \multicolumn{6}{|c|}{ The comprehensive development index $\left(I_{\text {total }}\right)$} \\
\hline & & \multicolumn{3}{|c|}{ Additive model } & \multicolumn{3}{|c|}{ Multiplicative model } \\
\hline & & 2016 & 2017 & $\begin{array}{l}\text { Growth } \\
\text { rate }\end{array}$ & 2016 & 2017 & $\begin{array}{l}\text { Growth } \\
\text { rate }\end{array}$ \\
\hline 1 & Austria & 0,842 & 0,814 & 0,97 & 0,836 & 0,809 & 0,97 \\
\hline 2 & Belgium & 0,802 & 0,794 & 0,99 & 0,797 & 0,789 & 0,99 \\
\hline 3 & Bulgaria & 0,705 & 0,662 & 0,94 & 0,683 & 0,648 & 0,95 \\
\hline 4 & Great Britain & 0,822 & 0,801 & 0,97 & 0,814 & 0,795 & 0,98 \\
\hline 5 & Hungary & 0,738 & 0,683 & 0,93 & 0,722 & 0,674 & 0,93 \\
\hline 6 & Germany & 0,824 & 0,806 & 0,98 & 0,818 & 0,800 & 0,98 \\
\hline 7 & Greece & 0,750 & 0,714 & 0,95 & 0,730 & 0,700 & 0,96 \\
\hline 8 & Denmark & 0,827 & 0,834 & 1,01 & 0,824 & 0,831 & 1,01 \\
\hline
\end{tabular}

\begin{tabular}{|l|l|l|l|l|l|l|l|}
\hline 9 & Ireland & 0,833 & 0,808 & 0,97 & 0,827 & 0,802 & 0,97 \\
\hline 10 & Spain & 0,806 & 0,769 & 0,95 & 0,797 & 0,761 & 0,96 \\
\hline 11 & Italy & 0,773 & 0,750 & 0,97 & 0,762 & 0,741 & 0,97 \\
\hline 12 & Latvia & 0,762 & 0,700 & 0,92 & 0,751 & 0,692 & 0,92 \\
\hline 13 & Lithuania & 0,766 & 0,715 & 0,93 & 0,755 & 0,707 & 0,94 \\
\hline 14 & Luxemburg & 0,825 & 0,795 & 0,96 & 0,819 & 0,791 & 0,97 \\
\hline 15 & Netherland & 0,829 & 0,810 & 0,98 & 0,825 & 0,806 & 0,98 \\
\hline 16 & Poland & 0,757 & 0,706 & 0,93 & 0,747 & 0,697 & 0,93 \\
\hline 17 & Portugal & 0,750 & 0,702 & 0,94 & 0,730 & 0,691 & 0,95 \\
\hline 18 & Romania & 0,741 & 0,685 & 0,92 & 0,732 & 0,679 & 0,93 \\
\hline 19 & Slovenia & 0,787 & 0,722 & 0,92 & 0,771 & 0,712 & 0,92 \\
\hline 20 & Finland & 0,857 & 0,823 & 0,96 & 0,854 & 0,820 & 0,96 \\
\hline 21 & France & 0,808 & 0,797 & 0,99 & 0,799 & 0,789 & 0,99 \\
\hline 22 & Croatia & 0,742 & 0,673 & 0,91 & 0,725 & 0,662 & 0,91 \\
\hline 23 & $\begin{array}{l}\text { the Czech } \\
\text { Republic }\end{array}$ & 0,798 & 0,745 & 0,93 & 0,792 & 0,739 & 0,93 \\
\hline 24 & Sweden & 0,855 & 0,823 & 0,96 & 0,850 & 0,819 & 0,96 \\
\hline 25 & Estonia & 0,771 & 0,696 & 0,90 & 0,755 & 0,685 & 0,91 \\
\hline $\begin{array}{l}\text { Mean for the EU } \\
\text { member-states }\end{array}$ & 0,757 & 0,720 & 0,95 & 0,748 & 0,714 & 0,95 \\
\hline
\end{tabular}

Source: Own calculations.

Table 11 presents calculation of the growth rate as correlation of the comprehensive development index in 2017 to its value in 2016 from the formula:

$$
T=\frac{I_{\text {total }} 2017}{I_{\text {total }}^{2016}}
$$

The calculation results of the future scenarios for the comprehensive development level according to two models are similar as the growth rates are in line. The next scenario conditions are set for this (Table 12). 
Table 12. Scenario conditions for the EU comprehensive development

\begin{tabular}{|l|l|l|l|l|}
\hline № & Indicator & Scenario & $\begin{array}{l}\text { The average } \\
\text { annual growth } \\
\text { rate }\end{array}$ & $\begin{array}{l}\text { Percent, } \\
\%\end{array}$ \\
\hline 1 & Additive and multiplicative & $\begin{array}{l}\text { Pessimistic } \\
\text { models }\end{array}$ & 0,95 & 95 \\
& Inertia & 0,98 & 98 \\
& Optimistic & 1,01 & 101 \\
\hline
\end{tabular}

Source: Own calculations.

Let us study the details of each scenario to identify the comprehensive development index by 2020. According to the optimistic scenario, the forecast calculates the continuation of the policy aimed at quantitative and qualitative welfare growth of the countries, which combines the development of economic, social and environmental spheres.

Let us assume that when political activities are implemented, the EU comprehensive development index calculated according to the optimistic scenario increases by $5 \%$. In this case the comprehensive development index growth rate is 1,01 (101\%).

The pessimistic scenario involves outdated methods, positive experience of the previous periods, while ignoring the objective need to fund certain components of development and wants differentiation to finance the end-chain. According to the defined scenario conditions, the growth rate of the comprehensive development index will be $0.95(95 \%)$.

The third scenario is inertia one, characterized by averaging between the optimistic and the pessimistic scenario. Under such conditions, the growth rate of the comprehensive development index will be 0.98 (98\%).

Our formula for calculating the future value of the comprehensive development index is as follows:

$$
I_{\text {total }}^{n+1}=\sqrt[3]{T \cdot I_{H D} \cdot I_{H A P} \cdot I_{E P I}}
$$

where $I_{\text {total }}^{n+1}$ - the comprehensive development index for $(n+1)$ year;

$I_{H D}$ - the human development index;

$I_{H A P}$ - the satisfaction with life index («happiness»);

$I_{E P I}$ - the environmental performance index;

$T$ - the growth rate according to scenario conditions, absolute value and $\%$.

The results of the scenario modelling are presented in Table 13. 
Table 13. The results of the scenario modelling of the EU comprehensive development index by 2020

\begin{tabular}{|l|l|l|l|l|l|}
\hline \multirow{2}{*}{ № } & \multirow{2}{*}{ Model } & \multirow{2}{*}{ Scenario conditions } & \multicolumn{3}{|l|}{ Years } \\
\cline { 3 - 6 } & & 2018 & 2019 & 2020 \\
\hline \multirow{3}{*}{1} & \multirow{2}{*}{ Additive model } & Pessimistic & 0,708 & 0,696 & 0,684 \\
\cline { 3 - 6 } & Inertia & 0,715 & 0,711 & 0,706 \\
\cline { 3 - 6 } & Optimistic & 0,723 & 0,725 & 0,728 \\
\hline \multirow{3}{*}{2} & \multirow{2}{*}{ Multiplicative model } & Pessimistic & 0,701 & 0,689 & 0,680 \\
\cline { 3 - 6 } & Inertia & 0,708 & 0,704 & 0,699 \\
\cline { 3 - 6 } & Optimistic & 0,716 & 0,718 & 0,721 \\
\hline
\end{tabular}

\section{Source: own calculation}

Table 13 shows that according to the optimistic scenario the additive model provides the highest value of the EU comprehensive development index by 2020 0,728 , the multiplicative model gives the least value 0,721 . It should be noted that during 2018-2020 the comprehensive development index will rise by 0,006 according to the additive model and by 0,005 according to the multiplicative model, which can be regarded as similar results. To illustrate the scenario conditions by separate models let us present them graphically in Figure 1 and Figure 2.

Figure 1. Scenario forecasting of the EU comprehensive development index by the additive model

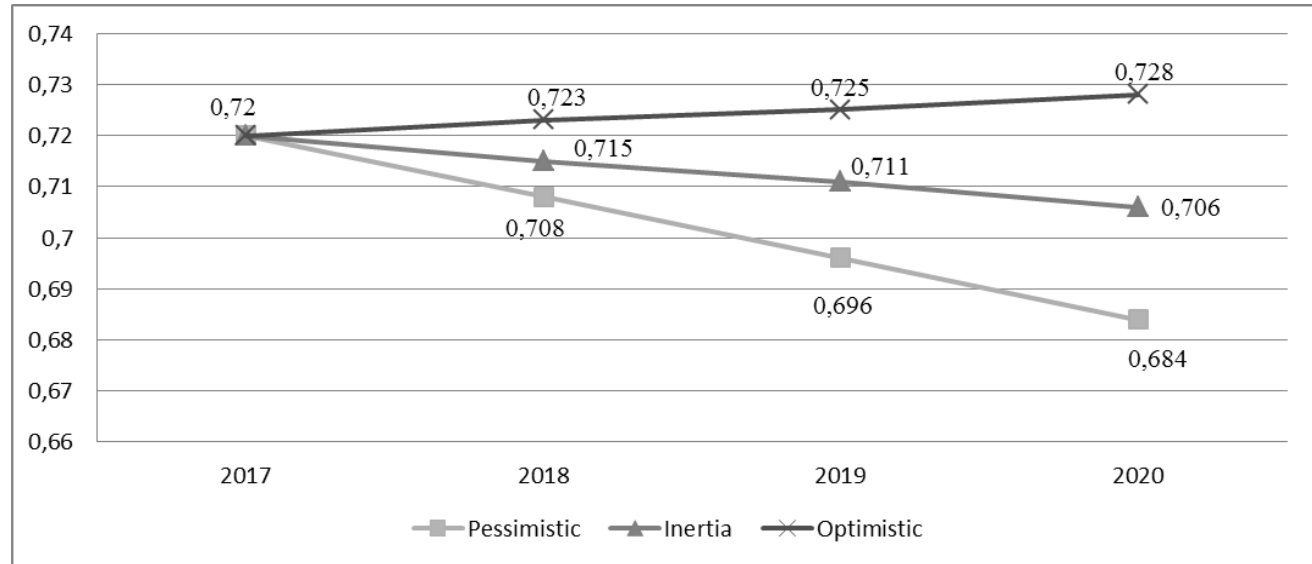

Source: Prepared by the authors.

Scenario analysis according to the additive model (Figure 1) gives the opportunity to state that this type of the determinate model gives the highest growth for the comprehensive development index by the optimistic scenario. The growth of comprehensive development index is 0,684 by the pessimistic scenario and 0,706 by the inertia scenario. Application of the multiplicative model in the context of the selected scenarios (Figure 2) is characterized by the lowering of the comprehensive development index according to the pessimistic scenario by 0,210 during 2018 2020 . It can be 0,009 contraction of the index value according to the inertia scenario 
during 3-year period. These results coincide with the additive model. The optimistic's model results for the comprehensive development index show that average annual development growth rate by the additive and multiplicative models will be $2,8 \%$.

Figure 2. Scenario forecasting of the EU comprehensive development index by the multiplicative model

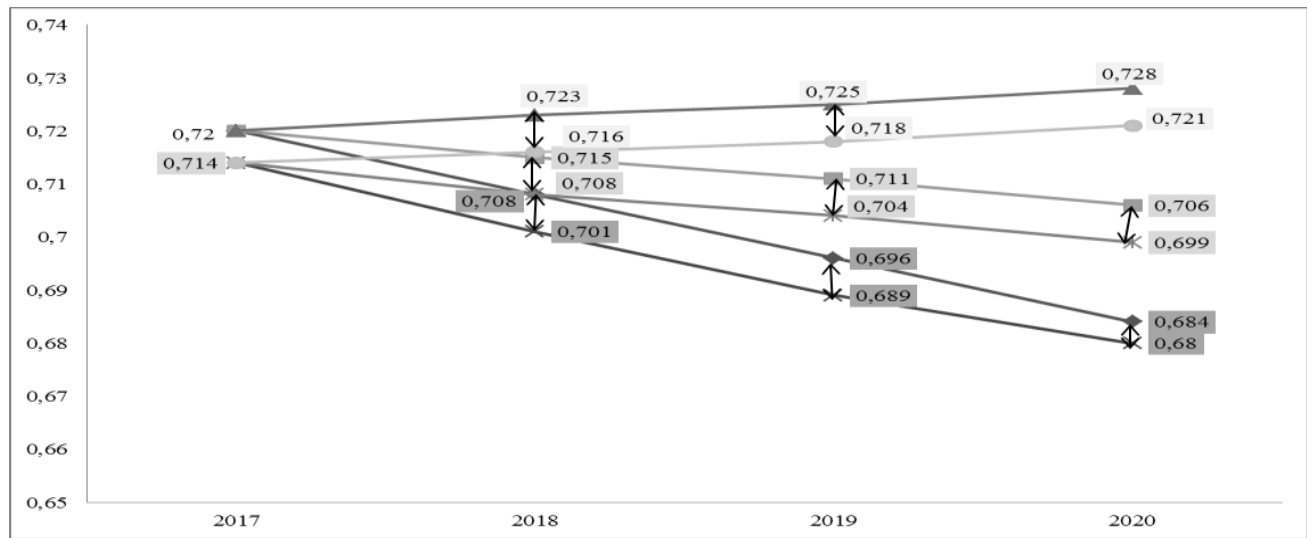

Source: Prepared by the authors.

Based on the obtained results according to the additive and multiplicative models one can calculate the value range for the comprehensive development inde by the selected scenario conditions (Figure 3).

Figure 3. Value range for the EU comprehensive development index according to the additive and multiplicative models by the selected scenario

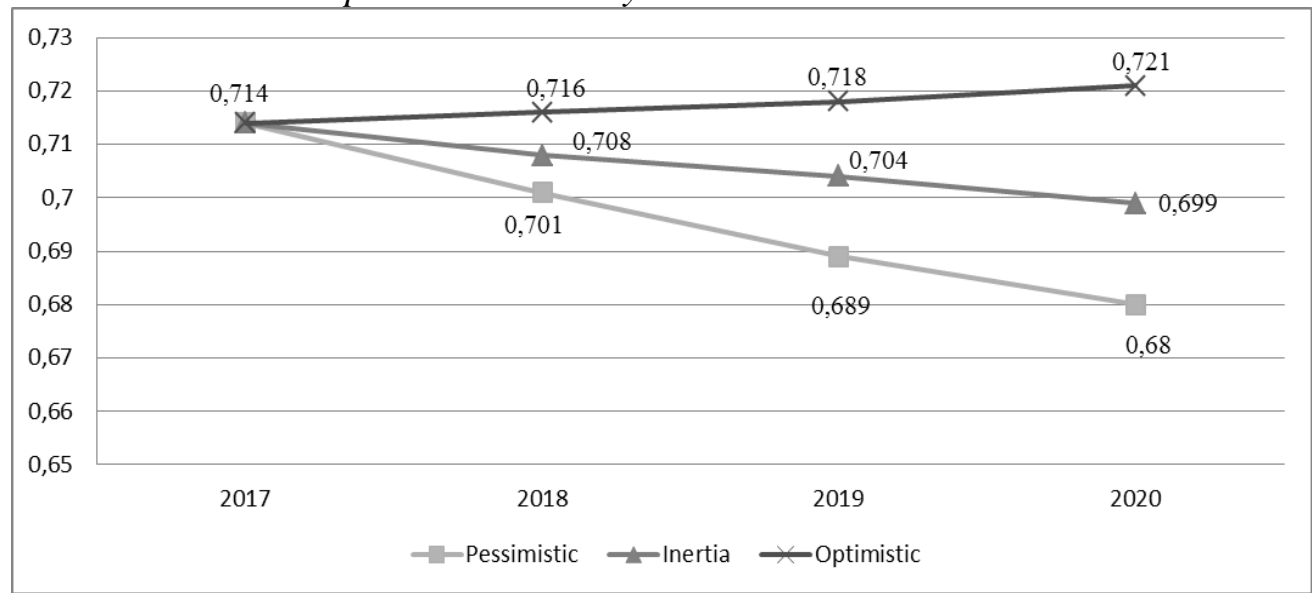

Source: Prepared by the authors.

We think that the built comprehensive development models give the opportunity not only to determine the dynamics of its components, but also to reveal national policy 
impact on the harmonization level of its components structure based on certain scenarios.

\section{Disscusion}

Theoretical and practical studies contain analysis of separate indicators, which characterize countries development. Easterlin (2010) was one of the first economists who examined the phenomenon of happiness. He analyzes the dependence of happiness on income levels. The scholar formulated "the Easterlin paradox", which states that people with higher incomes are generally happier than people with lower incomes, but the increase in their financial capacity gives less satisfaction to the first group than to the second. That is, the happiness index determines the level of satisfaction with life on the basis of separate components that determine correlation between country's well-being and the individual.

The Happiness Index estimates six components: GDP per capita, social safety, life expectancy at birth, ability to make individual vital decisions, generosity and attitudes toward corruption. Each component is ranked on 0 to 10 scale. This indicator not only determines the degree of "human involvement" in the processes, which take place in society, but also identifies the level of "satisfaction" from the participation.

The Human Development Index (HDI) is used to assess and compare levels of socio-economic status across countries. This universal indicator was introduced in international political and scientific sphere by the United Nations Organization in the framework of annual World Development Reports on Human Development according to the United Nations Development Program (UNDP) in 1990. HDI is a composite measure of human development that characterizes the average level of country`s achievements by three most important indicators of human development.

International experience of the developed countries proves that acknowledgment of the productive nature of investment in human development results in a balanced relation of economic and social components of social progress, social economy, high rates of development with a "Human Face" (Human development, United Nations Official Website). At the international level the Environmental Performance Index is used to characterize the level of safety`s environmental development (Environmental Performance Index- EPI). Nevertheless, all the above-mentioned indices are separately studied, that is the integrated approach is lacking.

We believe that each country aims not only to obtain high level of material wellbeing, but also to create living conditions that meet expectations of the population and form the environment for future generations based on ecosystem conservation. Therefore, the development of the comprehensive index is essential and relevant. 


\section{Conclusions}

Thus, the obtained results prove the theoretical background and practical calculations done by us based on statistical data for the EU member-states and illustrate high satisfaction with life index impact on the comprehensive development as well as positive human development impact and negative environmental performance impact. For convenience, we summarize the results for the hypotheses in Table 14.

\section{Table 14. Summary of findings}

\begin{tabular}{|l|l|}
\hline Hypotheses: & \\
\hline $\begin{array}{l}\text { H1: countries score higher human development index do not have to be top- } \\
\text { ranked country for the life satisfaction index }\end{array}$ & Is adopted \\
\hline $\begin{array}{l}\text { H2: the comprehensive development index includes many-component } \\
\text { country`s development }\end{array}$ & Is adopted \\
\hline $\begin{array}{l}\text { H3: development of a member-state of any association affects its internal } \\
\text { and external relations`strength as well as its sustainability }\end{array}$ & Is adopted \\
\hline
\end{tabular}

Source: Own study.

The obtained results testify contradictions and the existing imbalance of the "human development-life satisfaction-environmental performance" system. Countries with higher human development index do not have to be top-ranked countries for the life satisfaction index, which was proved in the study based on the EU member-states statistics analysis (hypothesis H1).

Therefore, we have developed and practically implemented fundamentally new approach to the assessment of comprehensive development through analytical substantiation and practical calculation of the comprehensive development index, which takes into account three dimensions: human development, life satisfaction and environmental performance (hypothesis H2).

Thus, the study shows that the development of an international association's member-state affects the strength of internal and external relations and its stability, which confirms the hypothesis $\mathrm{H} 3$. This raises the need to find out new models and effective tools for harmonizing national development components.

\section{References:}

Easterlin, R.A. 2011. The Happiness-Income Paradox Revisited. / A. Easterlin Richard, Laura Angelescu McVey, Malgorzata Switek et al. - IZA DP № 5799, URL: http://www.pnas.org/ content/early/2010/12/08/1015962107.full.pdf.

Environmental Performance Index. 2016. New Haven, CT, Yale University, URL: www.epi.yale.edu.

Human Development Data. 1990-2017. United Nations Development Programme Human Development Reports, URL: http://hdr.undp.org/en/data. 
Human development. UN. Available at: http://www.un.org.

Wendling, Z.A., Emerson, J.W., Esty, D.C. and Levy, M.A. et al. 2018. Environmental Performance Index. New Haven, CT, Yale Center for Environmental Law \& Policy. URL: https://epi.yale.edu/.

World Happiness Report. 2017. URL: https://s3.amazonaws.com/happinessreport/2017/HR17.pdf.

World Happiness Report. 2018. URL: https://s3.amazonaws.com/happinessreport/2018/HR18.pdf.

Yankovoi, A.G. 2010. Index models of factor economic analysis. Current technologies, business management, opportunities to apply information systems: proceeding of the 5th international scientific and practical conference. Odessa, ONU, 272-277.

Yankovoi, A.G. 2011. Comparative analysis of the methods of factor economic analysis based on multiplicative models. Statistical assessment of socio-economic development: proceedings of the all-Ukrainian scientific and practical conference, 20 April, Chmelnitsky, 18-23.

Yankovoi, A.G. 2011. Mathematical methods of factor economic analysis based on multiplicative models. Current technologies, business management, opportunities to apply information systems: proceeding of the 6th international scientific and practical conference, 31 March - 1 April, Odessa, ONU, 217-221. 